\title{
TENDENCJE NAZWOTWÓRCZE W CHREMATONIMII SPOŁECZNOŚCIOWEJ II RZECZYPOSPOLITEJ (NA PRZYKŁADZIE NAZW STOWARZYSZEŃ)
}

Słowa tematyczne: chrematonimia, socjoideonimy, nazwy stowarzyszeń, II Rzeczpospolita

\section{NAZWY STOWARZYSZEŃ JAKO OBIEKT BADAŃ}

Nazwy organizacji w porównaniu do innych kategorii nazewniczych, nawet w obrębie szeroko pojętej chrematonimii, stosunkowo rzadko są przedmiotem opracowań językoznawczych ${ }^{1}$. Edward Breza w wydanej w 1998 roku encyklopedii „Polskie nazwy własne” wymienił nazwy organizacji, towarzystw i stowarzyszeń wśród obszernej listy onimów, które nie zostały wówczas jeszcze opracowane (Breza, 1998, s. 347). W ciągu dwudziestu lat od wydania tejże pracy chrematonomastyka stała się w Polsce prężnie rozwijającą się gałęzią badań, diametralnie zmieniła się liczba opracowań dotyczących wielu grup nazewniczych wymienionych przez Brezę, zainteresowaniem jednak cieszą się głównie nazwy towarów i firm — sklepów, lokali usługowych itp. Na temat nazw stowarzyszeń również powstały opracowania, choć nie jest to grupa onimiczna tak często i wielostronnie omawiana przez językoznawców ${ }^{2}$, jak inne (Gałkowski,

1 Stwierdzenie to nie dotyczy tylko polskich ośrodków naukowych — stan badań nad nazwami organizacji oraz różne stanowiska językoznawców wobec tej i innych grup chrematonimów w onomastyce polskiej i słowiańskiej, a także we francuskiej i włoskiej przedstawił obszernie Artur Gałkowski w monografii „Chrematonimy w funkcji kulturowo-użytkowej” (Gałkowski, 2011a, s. 15-50). Zachodnioeuropejskie poglądy na chrematonimię scharakteryzowała również Barbara Czopek-Kopciuch (2011). Z obu opracowań można wysnuć wniosek, że uwaga badaczy zajmujących się szeroko pojętą chrematonimią, skupia się na nazwach związanych ze sferą marketingu, głównie na nazwach produktów i firm, nazwy organizacji są grupą onimów rzadko omawianą.

2 Gałkowski zwraca uwagę na fakt, iż nazwy zrzeszeń i organizacji są obiektem zainteresowań badaczy z innych dziedzin: „Problematyka nazwotwórcza zorganizowanych grup społecznych bywa poruszana przez socjologów, badaczy kultury, antropologów, socjolingwistów przy okazji prac dotyczących w sensie elementarnym struktur i działania organizacji” (Gałkowski, 2011a, s. 130). 
2011a, s. 130). Zainteresowania badaczy skupiały się na wybranych grupach nazw, m.in. towarzystw naukowych i hobbystycznych związanych z problematyką kosmiczną (Jakus-Borkowa, 2003, 2004), organizacji politycznych i banków (Nowakowska, Odaloš, 1999), organizacji i instytucji europejskich (Decyk, 1999), towarzystw naukowych i kulturalnych (Kowalik, 2011), duszpasterstw akademickich (Horyń, Zmuda, 2007). Z szeroko pojętego obszaru chrematonimii społecznościowej stosunkowo duże zainteresowanie wzbudzały nazwy klubów sportowych (Ożdżyński, 1973; Wilczyński, 1999; Jaruszewski, 2000; Lica, 2005; Dunaj, 2007).

Najobszerniej jak dotąd - w wymiarze teoretycznym i praktycznym nazwy organizacji opracował Artur Gałkowski w monografii „Chrematonimy w funkcji kulturowo-użytkowej”, w której poddał opisowi obszerny trójjęzyczny zbiór nazw stowarzyszeń, partii, fundacji itp. (Gałkowski, 2011a, s. 129-148). Teoretyczne kwestie związane z nazewnictwem organizacji i instytucji, podejmowane głównie przez Gałkowskiego i Jakus-Borkową (1987, 2003, 2004), dotyczą takich zagadnień, jak: swoistości tej grupy nazw wobec innych, ich miejsca w zasobie onimicznym języka oraz specjalistycznej terminologii.

Wśród swoistych cech wymienia się przede wszystkim deskryptywny charakter nazw organizacji, wskazując przy tym ich podobieństwo do wyrazów pospolitych:

Z wyrazami pospolitymi łączy je to, iż wszystkie one nie tylko oznaczają, ale także znaczą, niosą duży ładunek apelatywnej treści informacyjnej, spełniają rolę zbliżoną do funkcji tytułów czasopism, które od razu zainteresowanemu użytkownikowi mówią, czy jest właściwym odbiorcą, adresatem. Dzięki tym cechom, a także dzięki temu, iż mają one w większości formę deskrypcji jednostkowych, są przekładane z języka na język (Jakus-Borkowa, 2003, s. 595).

Stosunkowo łatwa przekładalność na języki obce stała się podstawą podważenia proprialności nazw organizacji przez Witolda Mańczaka (Mańczak, 2011, s. 327$)^{3}$, jest to jednak stanowisko skrajne i raczej odosobnione.

Podstawowy warunek proprialności — denotowanie tworów jednostkowych i pełnienie wobec nich funkcji identyfikacyjnej — nazwy organizacji spełniają w szczególny sposób, ze względów prawno-urzędowych niemożliwa jest bowiem ich powtarzalność. Akt nominacji przebiega zawsze oficjalnie - grupa

3 W artykule polemicznym wobec niektórych założeń A. Gałkowskiego W. Mańczak stwierdził kategorycznie: „,nazwy organizacji do kategorii nomina propria nie należą, gdyż przekłada się je z języka na język. Na przykład Liga Narodów nazywała się po francusku Ligue des Nations, po angielsku League of Nations, a po niemiecku Völkerbund. Partia hitlerowska zwała się po niemiecku Nationalsozialistiche Deutsche Arbeiterpartei, a po polsku Narodowosocjalistyczna Niemiecka Partia Robotnicza" (Mańczak, 2011, s. 327). Łatwa przekładalność jest tylko jedną z cech nazw organizacji; większość badaczy uznaje je za onimy, ale mniej prototypowe niż antroponimy bądź toponimy (Jakus-Borkowa, 2003, s. 593). 
osób chcących działać w sposób sformalizowany jest zobowiązana w momencie rejestracji do podania nazwy, przy czym ${ }^{4}$ :

Prawo o stowarzyszeniach nie określa, z czego powinna składać się nazwa stowarzyszenia. Wskazuje jedynie, że powinna ona odróżniać je od innych stowarzyszeń, organizacji i instytucji (...). Celem takiej regulacji jest zapobieganie ewentualnym omyłkom co do tożsamości podmiotów i zapewnienie bezpieczeństwa obrotu (Suski, 2002, s. 147).

Takie uregulowania prawne istnieją w Polsce już od lat trzydziestych XX wieku, kiedy to powstała pierwsza po odzyskaniu niepodległości polska ustawa o stowarzyszeniach (Krzysztofek, 2014, s. 52-64). Niepowtarzalność nazw uznaje Gałkowski za ważną swoistą cechę socjoideonimów, odróżniającą je od chrematonimów marketingowych, co do których nie stosuje się takich wymogów, w związku z czym „nieunikniona powtarzalność jest niepożądana, ale dopuszczalna, o ile nie chodzi o nazwę zastrzeżoną" (Gałkowski, 2011a, s. 132).

Inną charakterystyczną cechą chrematonimów społecznościowych jest ich funkcja socjotwórcza czy też dokładniej grupotwórcza — nadanie nazwy grupie osób, których połączył jakiś rodzaj więzi, stanowi ważny etap w procesie formalizowania wspólnoty:

[nazwa] sprzyja jej wyodrębnieniu, ale również jej definiowaniu jako zjawiska społecznego. Nazwa wchodzi w obieg komunikacyjny i nabiera znaczenia ideowego, tzn. utożsamiana jest z działalnością, funkcjami, historią, poglądami zrzeszenia (...) obecność [grupy] w świadomości społecznej jest możliwa dzięki nazwie, bo do niej odnoszą się wszystkie informacje, jakie wynikają z aktywności społecznej grupy (Gałkowski, 2011a, s. 129).

Jeśli chodzi o miejsce omawianych nazw w systemie onimicznym języka, specyfika nazw organizacji sytuuje je raczej w sferze „słabych” onimów, nieprototypowych (Jakus-Borkowa, 2003, s. 593). Takie usytuowanie wiąże się z przyjęciem stanowiska, iż proprialność jest w pewien sposób stopniowalna, ponieważ wobec dużej różnorodności nazw własnych nie można ustalić ,jednego paradygmatu formalnojęzykowego dla kategorii nomina propria" (Gałkowski, 2011b, s. 184). Nazwy organizacji mieszczą się w szerokim ujęciu chrematonimów - denotujących ,różnorodne realia, które są wynikiem kulturowej aktywności człowieka" (Gałkowski, 2011a, s. 9). Wśród nich mogą być także

nazwy obiektów ożywionych, głównie w odniesieniu do jednostek lub grup ludzi, jeśli te spełniają określone funkcje społeczne i stanowią strukturę formalnie zorganizowaną, np. nazwy form jednoosobowych (...) bądź nazwy stowarzyszeń gromadzących jednostki wokół określonej idei i pod jednym szyldem (Gałkowski, 2011b, s. 185).

4 W razie braku propozycji pochodzących od osób stowarzyszających się nazwa jest nadawana urzędowo. 
W literaturze przedmiotu nazwy stowarzyszeń są określane terminami: instytucjonimy (łac. institutio, -onis 'urządzenie'), ergonimy ${ }^{5}$ (gr. érgon 'dzieło, praca') (Breza, 1998, s. 348; Szelewski, 2004). Gałkowski zaliczył je natomiast do tzw. chrematonimii spotecznościowej (ChS) obok chrematonimii marketingowej (ChM), zawierającej nazwy firm i produktów, oraz chrematonimii ideacyj$n e j^{6}(\mathrm{ChI})$, obejmującej nazwy ,,przedsięwzięć oraz akcji o charakterze społecznym i kulturowym, które tworzą cywilizacyjne dziedzictwo wspólnot lokalnych, narodowych i międzynarodowych, grup skupionych wokół określonych celów i ideologii" (Gałkowski, 2011a, s. 191). Nazwy z dwóch grup, ChS i ChI, Gałkowski proponuje objąć wspólnym terminem socjoideonimy, które:

z dyskursywnego punktu widzenia charakteryzują się ogólnie większą intencją informacyjną, która czyni z socjoideonimów (...) specjalne „mikroteksty”, przemawiające do odbiorcy przekazem deskryptywnym lub kodowanym (socjotechnicznym) na temat nazywanej rzeczywistości (Gałkowski, 2011a, s. 53).

To właśnie ta swoista cecha socjoideonimów, jaką jest „większa intencja informacyjna", wynikająca z ich deskryptywnego charakteru i bezpośredniego odniesienia do nazywanej rzeczywistości, sprawia, że omawiana grupa nazw jawi się jako interesujący obiekt badań dla lingwistyki zorientowanej kulturowo.

\section{PODSTAWA MATERIAŁOWA}

Celem niniejszego artykułu jest pokazanie charakterystycznych cech strukturalno-semantycznych nazw stowarzyszeń z okresu II Rzeczypospolitej. Są one szczególnie interesujące ze względów historyczno-kulturowych, wydaje się jednak, że mogą być dobrym punktem wyjścia do opisu szerszych tendencji nazwotwórczych w tej grupie onimów i stać się płaszczyzną odniesienia do opracowania nazw współczesnych.

5 Termin ten używany jest też w rosyjskich badaniach onomastycznych na nazwanie jednej z kategorii równorzędnych w stosunku do takich jak: bionimy (antroponimy, zoonimy, fitonimy), toponimy, anemonimy, ideonimy, faleronimy, porejonimy, chrononimy, pragmatonimy, nomeny, przy czym — jak zwraca uwagę Gałkowski — w relacji równorzędności umieszczany jest też termin chrematonim, ,postrzegany jako nazwa pojedynczego wytworu kultury materialnej, czyli unikatonim" (Gałkowski, 2011a, s. 21). W onomastyce słowackiej proponuje się włączyć nazwy organizacji do pojemnej klasy logonimów (Horecký, 1994).

6 Wymienione grupy onimów mieszczą się — w ujęciu Gałkowskiego — w ramach szeroko pojętej chrematonimii użytkowej (ChU). Pojęcie chrematonimu użytkowego Gałkowski rozumie bardzo szeroko - są nimi „wszystkie nazwy własne, będące niejako językowym dowodem ludzkiej aktywności w różnych obszarach kulturowych życia publicznego: przestrzeni społecznej, gospodarczej, kulturalnej, artystycznej, ludycznej, edukacyjnej, naukowej, technicznej, religijnej, parareligijnej, ideologicznej, ekologicznej, prozdrowotnej, promującej lub potępiającej pewne postawy itp." (Gałkowski, 2011a, s. 51). 
Okres odradzania się państwa polskiego to czas tworzenia wielu organizacji społecznych, w których grupy osób o podobnych poglądach, doświadczeniach bądź celach pragnęły działać w obrębie jakiejś sformalizowanej wspólnoty i przyczynić się do budowania społeczeństwa obywatelskiego ${ }^{7}$. Organizacji społecznych działających w tym czasie było tak dużo, że powstawały specjalne publikacje mające ułatwić orientację w zróżnicowanych celach ich działalności, przesłankach ideologicznych lub formach aktywności. Jedna z takich publikacji posłużyła jako źródło ekscerpcji materiału do niniejszego artykułu. Jest to wydany w 1934 roku „Przewodnik społeczny” Antoniego Pruszkowskiego (Pruszkowski, 1934), w którym autor zaprezentował 250 stowarzyszeń, klasyfikując je na kilka grup: zrzeszenia młodzieży (46), zrzeszenia byłych wojskowych (50), zrzeszenia ogólnospołeczne (12), zrzeszenia kulturalno-oświatowe (13), zrzeszenia gospodarcze (44), organizacje kobiece (31), związki zawodowe (35), inne - różne - (28). Osobną kategorię stanowią nazwy z katolickiego ruchu społecznego, ale zostały one opisane w „Przewodniku społecznym” w sposób ogólny, z informacją, że pojedyncze katolickie organizacje pojawiły się w pozostałych grupach.

Różnorodność stowarzyszeń, spowodowana celem ich powstania oraz sferą życia, do której należą, znajduje częściowe odzwierciedlenie w zróżnicowaniu nazw w obrębie danej grupy. W dalszym ciągu artykułu omówione zostaną wspólne cechy analizowanych onimów, ze wskazaniem szczególnego ich nasilenia w ramach poszczególnych grup, jeśli taka swoistość da się zauważyć.

\section{ASPEKT STRUKTURALNY}

Cechą charakterystyczną omawianych struktur nazewniczych jest wyraźna przewaga form analitycznych (Gałkowski, 2011b, s. 186). W zebranym materiale dominują nazwy dwu-, trój- i czteroelementowe ${ }^{8}$, np. Stowarzyszenie Peowiaków ${ }^{9}$, Rodzina Wojskowa, Zwiazek Kobiet Pracujacych, Zwiazek Pracy Świetlicowej, Liga Obrony Powietrznej i Przeciwgazowej, Towarzystwo Rozwoju Ziem Wschodnich, Rada Naczelna Rzemiosta Polskiego.

7 Organizacje z okresu II RP są wciąż interesującym przedmiotem opracowań z zakresu historii, socjologii bądź prawa (por. m.in. Badziak, Walicki, 2002; Kantyka, 2013, Krzysztofek, 2014; Suski, 2002, s. 19-25, 247-253; Suski, 2008). Nazwy organizacji z dwudziestolecia międzywojennego wzbudziły także zainteresowanie w 2018 roku, w związku ze stuleciem odzyskania niepodległości, por. „Językowy obraz troski o Rzeczpospolitą utrwalony w nazwach stowarzyszeń" (Karamańska, Młynarczyk, 2018a), „Identyfikacja osób w nazwach organizacji kombatanckich II Rzeczpospolitej” (Karamańska, Młynarczyk, 2018b).

8 Za element nazwy uznano każdy wyraz, także synsemantyczny.

9 Ze względu na znaczne niekonsekwencje w zapisie nazw w tekście źródłowym, którego autor najwyraźniej nie przykładał wagi do spraw językowych, skupiając się na treściach merytorycznych, w niniejszym artykule pisownia została ujednolicona według współczesnych zasad ortograficznych. 
Nazwy dłuższe (od 5 do 10 elementów) występują zdecydowanie rzadziej, np. Stowarzyszenie Katolickiej Młodzieży Akademickiej „,Odrodzenie”, Zwiazek Bytych Uczestników Wojskowej Straży Kolejowej, Stowarzyszenie Weteranów Bytej Armii Polskiej we Francji, Zwiazek Polskich Samodzielnych Rzemieślników i Przemystowców w Poznaniu, Centralny Zwiazek Detalicznego Kupiectwa Chrześcijańskiego Rzeczpospolitej Polskiej w Warszawie, Centrala Stowarzyszeń Restauratorów, Hotelarzy i Pokrewnych Zawodów w Rzeczypospolitej Polskiej. Najdłuższa nazwa, wyjątkowa w całym zbiorze, składa się z czternastu elementów: Zwiazek Oficerów Internowanych w czasie Wojny Światowej w Obozach Polskich w Niemczech i Austrii.

Większość nazw ma postać zawiadomienia rzeczownikowego z rozbudowanymi przydawkami, zazwyczaj umieszczonymi prawostronnie, np.

\footnotetext{
Związek Byłych Uczestników Wojskowej Straży Kolejowej

Towarzystwo Popierania Budowy Publicznych Szkół Powszechnych

Związek Polskich Samodzielnych Rzemieślników i Przemysłowców w Poznaniu

Centrala Stowarzyszeń Restauratorów, Hotelarzy i Pokrewnych Zawodów Rzeczypospolitej Polskiej
}

Niektóre nazwy zawierają w swej strukturze odrębny człon wyróżniający, mający charakter metaforyczny, np.

Związek Młodzieży Wiejskiej Rzeczypospolitej Polskiej „Wici”

Stowarzyszenie Katolickiej Młodzieży Akademickiej „Odrodzenie”

Związek Młodzieży Pracującej „Jedność”

Towarzystwo „Nasz Dom”

Zjednoczenie Zawodowe „Praca Polska”

Towarzystwo „Kultura”

Nazwy z odrębnym członem wyróżniającym stanowią mniejszość w zebranym materiale, występują one zwłaszcza $\mathrm{w}$ nazwach zrzeszeń młodzieży (17 na 46), w których mają metaforyczny charakter i są nośnikami pozytywnych konotacji, najczęściej 'wspólnoty, więzi'. W pozostałych grupach brak w ogóle takich komponentów lub są pojedynczo reprezentowane, np. w nazwach zrzeszeń byłych wojskowych - jedyna taka nazwa (na 50) ma postać zawołania: Zwiazek Dowborczyków „Ku Chwale Ojczyzny”.

\section{INNE NAZWY WŁASNE JAKO KOMPONENTY SOCJOIDEONIMÓW}

Za charakterystyczną cechę socjoideonimów można uznać również występowanie w ich składzie innych nazw własnych ${ }^{10}$. Nie jest to typowa transonimizacja

${ }^{10}$ Tę cechę struktur nazewniczych Gałkowski odnosi do wszystkich chrematonimów: „Środowisko ChU to prawdopodobnie najbogatszy obszar nazewnictwa transonimizacyjnego. Wśród 
(przeniesienie nazwy własnej na inny obiekt, por. Kosyl, 1993, s. 441), występująca szczególnie często w chrematonimii marketingowej, ale włączanie elementów proprialnych jako komponentów struktury nazewniczej. W badanym materiale wystąpiły:

- toponimy jako komponenty wskazujące obszar działalności stowarzyszenia, miejsce jego powstania lub w inny sposób związane $\mathrm{z}$ daną organizacją; mogą to być nazwy państw (m.in. Polska, Rzeczpospolita Polska (także skrót: R.P.), Belgia, nazwy regionów, ziem (m.in. Śląsk, Kresy Wschodnie, Ziemie Zachodnie), miast (Lwów), np.

Legia Inwalidów Wojennych Rzeczpospolitej Polskiej im. gen. Józefa Sowińskiego

Związek Ociemniałych Żołnierzy R.P.

Związek Byłych Wojskowych Polskich w Belgii

Związek Powstańców i Byłych Żołnierzy na Śląsku

Stowarzyszenie Obrońców Kresów Wschodnich

Związek Podoficerów Rezerwy Ziem Zachodnich

- socjoideonimy, nazwy organizacji, instytucji, jednostek wojskowych, występujące głównie w nazwach organizacji kombatanckich (np. Wojskowa Straż Kolejowa; Straż Obywatelska, Związek Broni, I Brygada Legionów Polskich) oraz w nazwach federacji, central, w których wystąpiły nie tyle nazwy konkretnych organizacji, co ich grupy (np. komponenty o postaci: związki Polek, związki obrońców Ojczyzny), m.in.

Związek Byłych Uczestników Wojskowej Straży Kolejowej

Związek Byłych Członków Straży Obywatelskiej 1915 Roku

Związek Byłych Kurierek I Brygady Legionów Polskich

Stowarzyszenie Uczestniczek Byłego Związku Broni

Federacja Polskich Związków Obrońców Ojczyzny

Zjednoczenie Katolickich Związków Polek

- akcjonimy - nazwa wydarzenia historycznego, powstanie wielkopolskie, jest obecne w nazwie jednego ze stowarzyszeń byłych wojskowych:

Związek Uczestników Powstania Wielkopolskiego ${ }^{11}$.

nazw ChM, ChS i ChI spotykamy przykłady wywodzące się w większości z innych kategorii onomastycznych, które służą za podstawę chrematonimotwórczą" (Gałkowski, 2011a, s. 231). Sąd ten znajduje uzasadnienie w licznych przykładach trójjęzycznych nazw prezentowanych w monografii Gałkowskiego.

11 W nazwach stowarzyszeń kombatanckich także inne komponenty mogą odnosić się do wydarzeń historycznych, ale w sposób bardziej ogólny, np. Zwiazek Uczestników-Żydów Walk o Niepodległość, lub presuponowany - przez podanie roku, np. Towarzystwo Przyjaciót Weteranów z $1863 \mathrm{r}$. Akcjonimy są również obecne pośrednio - w komponentach rzeczownikowych od nich derywowanych, np. Związek Powstańców Śląskich, Związek Powstańców Wielkopolskich. 
Szczególny charakter mają antroponimy ${ }^{12}$ obecne w nazwach stowarzyszeń, np.

Instytut Oświaty i Kultury im. Staszica

Uniwersytet Ludowy im. A. Mickiewicza we Lwowie

Związek Katolickiej Służby Żeńskiej pod wezwaniem św. Zyty

Stowarzyszenie Pań Miłosierdzia św. Wincentego a Paulo

Ten element struktury nazewniczej można nazwać komponentem patronalnym - nazwą własną wprowadzaną w skład socjoideonimu za pomocą dopełniaczowej formy rzeczownika imienia (skrót im.) lub wyrażenia pod wezwaniem. Komponent ten ma na celu podkreślenie, iż członkowie danej organizacji utożsamiają się z działalnością, ideami, postawą ważnej dla nich postaci świętego lub osoby związanej (historycznie, ideologicznie itp.) z daną organizacją ${ }^{13}$.

Komponent patronalny może być jedynym członem wyróżniającym, jak np. w nazwie Towarzystwo im. Piotra Skargi, w której postać patrona wskazuje na religijny charakter stowarzyszenia.

\section{KOMPONENT GŁÓWNY}

Identyfikacja obiektu nominacji jako stowarzyszenia grupy osób następuje w analizowanych strukturach poprzez komponent główny o znaczeniu 'sformalizowana grupa ludzi' ${ }^{14}$. Najczęściej w tej funkcji występują rzeczowniki: zwiqzek (95), np. Zwiazek Pracy Obywatelskiej Kobiet, Zwiazek Uchodźców Ślaskich, Polski Zwiazek Niewiast Katolickich; towarzystwo (38), np. Towarzystwo Przyjaciót Młodzieży Akademickiej, Towarzystwo Przyjaciót Huculszczyzny, Towarzystwo Czytelń Ludowych; stowarzyszenie (25), np. Stowarzyszenie Oświaty Robotniczej, Stowarzyszenie Bylych Więźniów Politycznych. Inne leksemy występują zdecydowanie rzadziej: legion - Legion Bytych Ochotników Wojsk Polskich; legia - Legia Inwalidów Wojennych Rzeczpospolitej Polskiej im. gen. Józefa Sowińskiego; liga — Liga Kobiet; koto — Koło Polek; organizacja Organizacja Przysposobienia Kobiet do Obrony Kraju; rada - Rada Narodo-

${ }^{12}$ Gałkowski uważa, iż „szczególnie dużo antroponimów wchodzi w skład nazw stowarzyszeń i fundacji społecznych oraz innych zrzeszeń ludzkich, ale również nazw konkursów, festiwali, nagród, świąt świeckich i innych ludzkich działań w życiu publicznym” (Gałkowski, 2011a, s. 232).

${ }_{13} \mathrm{~W}$ analizowanym materiale jako komponent patronalny wystąpiły wyłącznie antroponimy, ale obserwacja współczesnych socjoideonimów wskazuje, że mogą nim być również nazwy innych obiektów rzeczywistości, m.in. instytucji —. Uniwersytet Pedagogiczny im. Komisji Edukacji Narodowej, formacji wojskowych — Zespót Placówek Oświatowych im. Pierwszej Kompanii Kadrowej, zjawisk nadprzyrodzonych — Kościót pod wezwaniem Opatrzności Bożej.

${ }_{14}$ Postać tego komponentu nie jest prawnie uregulowana - nazwa nie musi zawierać leksemu stowarzyszenie, w samych aktach normatywnych istnieje w tym względzie duże zróżnicowanie (Kantyka, 2013, s. 147). 
wa Polek. Niektóre komponenty wnosily dodatkowe konotacje, np. 'bliskości' i 'troski' - rzeczownik rodzina użyty w kilku analogicznie utworzonych nazwach - Rodzina Wojskowa, Rodzina Pocztowa, Rodzina Policyjna, Rodzina Urzędnicza. Były to organizacje samopomocowe zrzeszające najbliższe rodziny, głównie żony, wojskowych bądź funkcjonariuszy państwowych (Pruszkowski, 1934, s. 207-208) $)^{15}$. Inny rzeczownik - macierz, niosący skojarzenia zarówno z matką, jak i z ojczyzną, występuje jako główny komponent w nazwie jednej z najstarszych polskich organizacji oświatowych, założonej w $1906 \mathrm{r}$. (jeszcze w czasie zaborów, co miało zapewne wpływ na wybór tego komponentu): Polska Macierz Szkolna i analogicznych, działających w różnych miejscach Polski: Macierz Szkolna Księstwa Cieszyńskiego ${ }^{16}$, Macierz Szkolna w Gdańsku.

W nazwach kilku stowarzyszeń o charakterze naukowym bądź edukacyjnym (Instytut Battycki, Instytut Oświaty Dorostych) jako człon konstytutywny wystąpił leksem instytut, niosący skojarzenia z tą sferą aktywności społecznej.

Komponent główny mógł też nazywać związek zrzeszeń, rodzaj federacji, które tworzyły bliskie pod jakimś względem organizacje. Mogły to być rzeczowniki wyspecjalizowane w tym znaczeniu — zjednoczenie (Zjednoczenie Katolickich Zwiąków Polek), unia (Unia Zwiąków Zawodowych Pracowników Umystowych) lub inne leksemy obecne w nazwach pojedynczych stowarzyszeń, np. Centralne Towarzystwo Organizacji i Kótek Rolniczych, Związek Towarzystw Polek.

W zebranym materiale zdarzają się także nazwy wyłącznie symboliczne, bez komponentu oznaczającego 'grupę ludzi', występują one jednak zdecydowanie rzadziej, np. Polski Biaty Krzyż, Polski Czerwony Krzyż, Wolna Wszechnica Polska, Młodziez Wszechpolska ${ }^{17}$.

\section{POZOSTAŁE KOMPONENTY}

Pozostałe komponenty struktury nazewniczej to przydawki określające człon główny, które mogą być usytuowane lewostronnie, np.

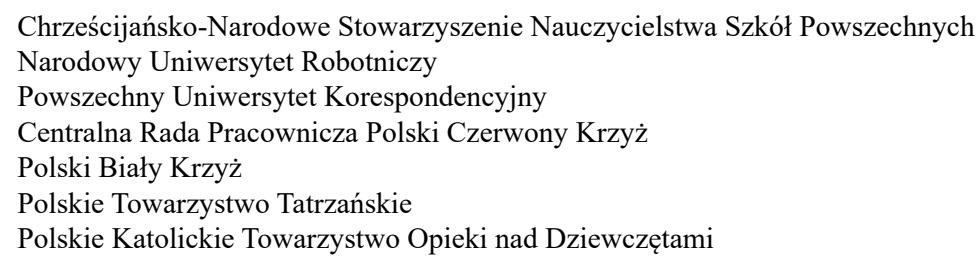

${ }^{15}$ Organizacje te zajmowały się pomocą m.in. dla wdów i sierot po wojskowych bądź urzędnikach państwowych (Pruszkowski, 1934, s. 207-208).

16 Stowarzyszenie to powstało jeszcze wcześniej - w $1885 \mathrm{r}$.

$17 \mathrm{~W}$ tej nazwie za komponent wskazujący grupę ludzi można uznać rzeczownik zbiorowy młodzież, ma on jednak znaczenie ogólne, bez elementu semantycznego 'sformalizowana grupa'. 
Występujący w tej pozycji przymiotnik zazwyczaj wskazuje zasięg działalności organizacji (powszechny, narodowy, polski), z tym że leksem polski bywa też sygnałem, iż mamy do czynienia $\mathrm{z}$ krajowym oddziałem organizacji międzynarodowej (jak Polski Czerwony Krzyż, Polski Biały Krzyż).

Większość struktur nazewniczych jest rozbudowana przez prawostronne wieloskładnikowe przydawki, np.

Polskie Stowarzyszenie Kobiet z Wyższym Wykształceniem

Towarzystwo Bibliotek Publicznych w Warszawie

Stowarzyszenie Byłych Więźniów Politycznych

Związek Byłych Żołnierzy Lekkiej Brygady III Korpusu WP na Wschodzie

\section{ASPEKT SEMANTYCZNY}

Ogląd pozostałych, prócz członu głównego, komponentów tworzących analizowane socjoideonimy wskazuje, że uszczegółowiają one przede wszystkim różne podstawy wspólnotowości osób zrzeszonych. Identyfikacja tejże wspólnotowości następuje w sposób mniej lub bardziej szczegółowy, co ma bezpośrednie przełożenie na rozbudowanie struktur nazewniczych. Zazwyczaj w jednej nazwie łączone są różne sposoby identyfikacji, analizując jednak poszczególne komponenty pod względem semantycznym, można wskazać pewne powtarzające się elementy i ich leksykalne wykładniki ${ }^{18}$. Są to:

- wspólnota doświadczeń, najbardziej wyraziście eksponowana w nazwach kombatanckich, których członkowie podkreślali swoje uczestnictwo w działaniach militarnych lub paramilitarnych poprzez rzeczowniki osobowe, m.in. weteran, uczestnik, obrońca łączone $\mathrm{z}$ wyrażeniami nazywającymi wydarzenia historyczne (weterani powstań narodowych, obrońcy Lwowa, uczestnicy walk o niepodległość) lub derywaty powstałe od nazw jednostek sił zbrojnych, m.in. peowiacy, peowiaczki (< POW — Polska Organizacja Wojskowa), legioniści, legionistki (< Legiony Polskie) bądź też nazywające osoby ze względu na ich udział w represjach czy wymuszonych działaniach (sybiracy, optanci $i^{19}$, reemigranci ${ }^{20}$ ) lub inne, $\mathrm{np}$.

Związek Weteranów Powstań Narodowych

Stowarzyszenie Obrońców Kresów Wschodnich

Związek Obrońców Lwowa z listopada 1918 roku

${ }^{18}$ Ze względu na łączenie w nazwach kilku cech wspólnotowych nazwy niektórych organizacji mogą występować jako przykłady w więcej niż jednej grupie.

19 optant 'osoba uprawniona do wyboru obywatelstwa, korzystająca z przysługującego jej prawa opcji' (SJPDor).

20 reemigrant 'wychodźca, emigrant powracający do ojczyzny' (SJPDor). 
Związek Peowiaków

Związek Legionistek Polskich

Związek Legijonistów Polskich

Związek Powstańców i Wojaków O.K. VIII

Związek Sybiraków

Związek Optantów i Reemigrantów z Niemiec

- status zawodowy i społeczny - to typ wspólnotowości występujący głównie w organizacjach o charakterze społeczno-zawodowym, w których nazwach tożsamość osób zrzeszonych realizują rzeczowniki nazywające konkretne zawody (np. kolejowiec, rolnik) lub rolę społeczną (matka, pani domu) oraz rzeczowniki zbiorowe (nauczycielstwo 'ogół nauczycieli') bądź wyrażenia wskazujące w sposób ogólny sam fakt zatrudnienia (kobieta pracująca ${ }^{21}$ ):

Zjednoczenie Kolejowców Polskich

Śląski Związek Rolników

Stowarzyszenie Matek Chrześcijańskich

Związek Pań Domu

Związek Nauczycielstwa Polskiego

Związek Niższych Funkcjonariuszy Państwowych

Towarzystwo Klubów Kobiet Pracujących

- cel działalności, eksponowany zwłaszcza w stowarzyszeniach ogólnospołecznych, uszczegółowiony zazwyczaj poprzez wyrażenia z leksemami nazywającymi rodzaj aktywności (m.in. opieka, pomoc, przysposobienie, popieranie, obrona) lub dziedzinę, na której skupiają się członkowie organizacji (m.in. oświata, rozwój, wolna myśl), np.

Towarzystwo Opieki nad Niezatrudnioną Młodzieżą

Stowarzyszenie Wzajemnej Pomocy Weteranów z 1863 roku

Organ Przysposobienia Kobiet do Obrony Kraju

Towarzystwo Popierania Budowy Publicznych Szkół Powszechnych

Liga Obrony Czci

Instytut Oświaty Dorosłych

Towarzystwo Rozwoju Ziem Zachodnich

Polski Związek Myśli Wolnej

- pleć, eksponowana w nazwach organizacji kobiecych poprzez leksemy i wyrażenia kobieta, pani, pani domu, pani miłosierdzia lub feminatywne derywaty słowotwórcze — Polka, ziemianka, drużyniaczka, peowiaczka, strzel$c z y n i^{22}, \mathrm{np}$.

${ }^{21}$ Tak ogólnie sformułowana informacja była ważnym wyróżnikiem w nazwach organizacji kobiecych II RP, ponieważ wskazywała na zawodowy i społeczny status kobiet.

${ }^{22}$ A. Małocha-Krupa w monografii „Feminatywa w uwikłaniu językowo-kulturowym”, omawiając kilkanaście nazw żeńskich, które stały się komponentami nazw stowarzyszeń, zauważa: „Wzmożony wzrost świadomości emancypacyjnej, jaki nastąpił w II połowie XIX wieku, zaowocował m.in. możliwością samoorganizowania się i zrzeszania w rozmaitego typu organizacjach, 
Liga Kobiet

Polskie Towarzystwo Kobiet z Wyższym Wykształceniem

Związek Pań Domu

Stowarzyszenie Pań Miłosierdzia św. Wincentego a Paulo

Stowarzyszenie Zjednoczonych Ziemianek

Stowarzyszenie Peowiaczek

Związek Byłych Kurierek

Związek Legionistek Polskich

Stowarzyszenie Strzelczyń 1912/14

— przynależność pokoleniowa, podkreślana wyłącznie w nazwach organizacji zrzeszających ludzi młodych, identyfikowana za pomocą rzeczownika zbiorowego młodzież, np.

Związek Polskiej Młodzieży Demokratycznej

Związek Niezależnej Młodzieży Socjalistycznej

Towarzystwo Przyjaciół Młodzieży Akademickiej

— tożsamość religijna, wyróżniana w nazwach przymiotnikami katolicki, chrześcijański, np.

Liga Katolicka

Chrześcijański Związek Rękodzielniczy „Dźwignia”

Związek Katolickiej Służby Żeńskiej pod wezwaniem św. Zyty

— narodowość, identyfikowana leksemami Polka, Żyd, np.

Koło Polek

Związek Żydów Uczestników Walk o Niepodległość Polski

— ideologia, stosunkowo rzadko podkreślana w nazwach ze względu na wymaganą apolityczność stowarzyszeń ${ }^{23}$; $w$ analizowanych przykładach komponent „ideologiczny” zawierają głównie nazwy organizacji młodzieżowych, m.in.

Związek Niezależnej Młodzieży Socjalistycznej

Związek Polskiej Młodzieży Demokratycznej

stowarzyszeniach i związkach kobiecych (...). Większość wspólnot kobiecych powstających w owym okresie, kiedy obierała nazwę dla swojej działalności, najwyraźniej dostrzegała konieczność naznaczenia jej parametrem płci. W związku z otwierającą się nową przestrzenią publiczną dla kobiet oraz możliwością ich zrzeszania się dyskurs emancypacyjny dostarcza zróżnicowanej egzemplifikacji instytucjonimów, których cechą charakterystyczną okazuje się eksplikacja dodatkowego parametru [+żeńskość], obecnego w strukturach nominalnych typu organizacja [+żeńskość], stowarzyszenie [+żeńskość]" (Małocha-Krupa, 2018a, s. 106).

${ }^{23}$ Spory ideologiczne były powodem powstawania lub podziału stowarzyszeń o innych podstawach wspólnotowości, np. wśród nazw młodzieżowych: Związek Młodzieży Ludowej (prorządowy), Związek Młodzieży Wiejskiej Rzeczypospolitej Polskiej „Wici” (związany ściśle ze Stronnictwem Ludowym, o tendencjach antyklerykalnych i antyrządowych). Zorientowaniu się w wielości ideologicznych różnic miały służyć przewodniki, m.in. Pruszkowskiego, który stał się podstawą niniejszego opracowania (Pruszkowski, 1934). 
- miejsce działalności lub założenia, uściślane przez komponent toponimiczny występujący zazwyczaj w końcowej części nazwy, wskazujący miejsce — kraj, region lub miasto — w którym dana organizacja powstała i/lub działa lub jest z nim jakoś związana:

Związek Powstańców i Byłych Żołnierzy na Śląsku

Związek Byłych Wojskowych Polskich w Belgii

Zjednoczenie Polskich Kupców i Przemysłowców Chrześcijan w Wilnie

Towarzystwo Bibliotek Publicznych w Warszawie

Rada Organizacyjna Polaków z Zagranicy

W większości prezentowanych nazw różne podstawy wspólnotowości są łączone, np. Zjednoczenie Polskich Kupców i Przemystowców Chrześcijan w Wilnie - 'przynależność zawodowa' (jako główny element tożsamości), 'narodowość', 'religia', 'miejsce działalności'; Zwiazek Żydów Uczestników Walk o Niepodległość Polski — 'narodowość', 'wspólnota doświadczeń'; Stowarzyszenie Wzajemnej Pomocy Weteranów z 1863 roku 'wspólnota doświadczeń', 'cel działalności'. Bez względu jednak na to, czy dany element był eksponowany jako podstawowy czy jako dodatkowy — miał taką samą moc włączania bądź wykluczania kogoś z organizacji.

Mimo rozbudowania nazw i ich deskryptywnego charakteru nie wszystkie, czasem bardzo istotne, informacje zostały wyrażone w nich eksplicytnie. Można je uszczegółowić dopiero na podstawie statutu bądź opisu w przewodnikach, np. Towarzystwo Osiedle — było instytucją opiekuńczą, Instytut Battycki — organizacją badawczo-naukową, a Rodzina Wojskowa, podobnie jak Rodzina Pocztowa czy Urzędowa - to zorganizowane grupy pomocowe. Należy też podkreślić, że konspiracyjne stowarzyszenia powstałe w czasie zaborów, prowadzące działalność narodowowyzwoleńczą pod pozorem (czy też obok) innych aktywności, nosiły nazwy nieeksponujące prawdziwego celu, np. Związek Towarzystw Gimnastycznych ,Sokót”.

\section{PODSUMOWANIE}

Powyższa analiza pozwala na wysnucie wniosków co do głównych tendencji nazwotwórczych w nazwach stowarzyszeń II Rzeczypospolitej.

1. W zakresie struktury - charakterystyczną tendencją jest tworzenie rozbudowanych, kilkuelementowych nazw oraz ich deskrypcyjny charakter; cechy te mogą wynikać z kilku czynników:

— dążenia do przekazania wyrazistej informacji na temat zrzeszonych osób i różnych podstaw ich wspólnotowości; rozbudowanie struktur zależne jest m.in. od stopnia uszczegółowienia informacji zawieranych w nazwie 
— intencjonalnego eksponowania w nazwach pewnych cech, wartości lub informacji ważnych z punktu widzenia osób tworzących organizację

— podkreślania specyfiki zrzeszającej się grupy społecznej wobec innych, powstałych wcześniej; szczególnie w przypadku istnienia podobnych zrzeszeń lub wyodrębniania się grupy z większej struktury organizacyjnej

— wspomnianego wyżej urzędowego wymogu wyraźnego różnicowania nazw z zakresu chrematonimii społecznościowej, co łączyło się z koniecznością podkreślania cech dyferencyjnych wobec innych ugrupowań.

2. Deskryptywność nazw i wynikająca $\mathrm{z}$ tej cechy informatywność łączą się $z$ brakiem charakterystycznych dla chrematonimów marketingowych elementów gier językowych czy konstrukcji zmuszających odbiorcę do deszyfracji tekstu. Twórcy nazw stowarzyszeń z okresu II Rzeczypospolitej starali się raczej nadać im formę jasnego, wyrażonego wprost komunikatu. Metaforyczny charakter mają jedynie zastosowane w niektórych nazwach odrębne człony identyfikacyjne, stosowane głównie w organizacjach młodzieżowych, w których dzięki tym komponentom przekazywano dodatkowe, asocjacyjne treści.

3. Jedną $z$ tendencji widocznych $w$ analizowanej grupie jest włączanie w struktury onimiczne innych nazw własnych, które miały na celu zwrócenie uwagi odbiorców na utworzenie wspólnoty wokół pewnego obiektu rzeczywistości pozajęzykowej: formacji wojskowej, miejsca, wydarzenia, innej organizacji lub osoby. W niektórych nazwach organizacji szczególną rolę pełni komponent patronalny realizowany przez antroponimy, wprowadzany jako sygnał utożsamiania się członków organizacji z postawą i ideami świętego lub innej ważnej dla nich postaci.

4. Członem konstytutywnym omawianych struktur jest rzeczownik pełniący funkcję identyfikacyjną w stosunku do oznaczanego obiektu (denotatu), mający znaczenie 'sformalizowana grupa osób'. Najczęściej w tej funkcji występują: zwiazek, towarzystwo, stowarzyszenie. Rozbudowanie nazw następowało poprzez kilkuelementowe przydawki, zazwyczaj usytuowane prawostronnie.

5. Pod względem semantycznym w prezentowanych strukturach socjoideonimicznych zwracają uwagę przede wszystkim składniki nazywające różne podstawy wspólnotowości osób zrzeszonych. Były to: wspólnota doświadczeń, status zawodowy i społeczny, cel działalności, płeć, przynależność pokoleniowa, tożsamość religijna, narodowość, ideologia, miejsce działalności lub założenia. Wymienione składniki są łączone w większości nazw. Ich dobór jest do pewnego stopnia zależny od rodzaju organizacji, w poszczególnych grupach występowały bowiem podobne elementy semantyczne świadczące o podstawach, na jakich opierały się wspólnoty zrzeszonych. 
6. Polskie nazwy stowarzyszeń z okresu dwudziestolecia międzywojennego bazują na leksyce rodzimej, o dużym ładunku treści presuponowanych, co szczególnie jest widoczne w nazwach organizacji kombatanckich odwołujących się do polskiej historii, np. komponenty nazywające osoby - powstańcy, uczestnicy walk o niepodległość, optanci, reemigranci, murmańczycy, hallerczycy, kaniowczycy, wydarzenia historyczne, niektóre sugerowane tylko przez datę - Związek Obrońców Lwowa z listopada 1918 roku, Stowarzyszenie Wzajemnej Pomocy Weteranów z 1863 roku lub przez nazwę formacji wojskowej - Zwiazek Żotnierzy Bytego I Korpusu Wschodniego. Rodzimość leksyki wynika ze specyfiki nazywanych obiektów oraz z zasięgu działania omawianych organizacji, mających w większości narodowy charakter $^{24}$.

7. Na przykładzie analizowanych historycznych nazw widać wyraźny związek socjoideonimów z realiami, których dotyczą, i związaną z tym informatywność. Stopień ich właściwego odczytania zależny jest od kulturowej, historycznej i językowej kompetencji odbiorcy. Deskryptywny charakter nie oznacza wcale całkowitej zrozumiałości i pełnej przekładalności na języki obce. Powstałe w ściśle określonym czasie i miejscu są nośnikami wyrazistych treści historyczno-kulturowych, w szczególny sposób zatem potwierdzają powszechnie przyjmowany w onomastyce sąd, sformułowany m.in. przez Zofię Kaletę w encyklopedii „Polskie nazwy własne”: „W nazwach własnych znalazły odbicie różne zjawiska i fakty $\mathrm{z}$ historii narodu, jego kultury materialnej i duchowej, życia religijnego, a także system wartości, który uznawali nasi przodkowie." (Kaleta, 1998, s. 70). Stwierdzenie to, uzasadnione mocno w literaturze przedmiotu różnymi zjawiskami z zakresu toponimii i antroponimii, w sposób szczególny dotyczy socjoideonimów, zwłaszcza historycznych, ze względu na ich ścisłe powiązanie $z$ wieloma zjawiskami społecznymi, wydarzeniami historycznymi czy zmianami ideologicznymi. Wydaje się, że dzięki temu analizowana grupa onimów może stanowić niezwykle interesujący obiekt badań dla kulturowo zorientowanej lingwistyki, w szczególny sposób w ujęciu diachronicznym.

8. Zanalizowane nazwy mogą stanowić materiał porównawczy do analizy współczesnych socjoideonimów. Takie badania mogłyby przynieść odpo-

${ }^{24} \mathrm{Na}$ zależność składu leksykalnego od zasięgu działania organizacji zwróciła uwagę Jakus-Borkowa, analizując chrematonimy kosmiczne, w której dominują tzw. chrematonimy globalne, obcojęzyczne. Wynika to ze specyfiki badań kosmicznych prowadzonych zazwyczaj w ramach międzynarodowej współpracy uczonych, dzięki czemu większość nazw własnych z tej dziedziny powstaje w ,ponadnarodowych wspólnotach komunikatywnych według ustalonych reguł onimicznych”, przy czym większość chrematonimów kosmicznych ma swoje narodowe odpowiedniki dostosowane do norm urzędowych (Jakus-Borkowa, 2003, s. 594). 
wiedź na pytanie, na ile trwałe są tendencje widoczne w strukturach onimicznych dwudziestolecia międzywojennego.

\section{ŹRÓDŁO}

Pruszkowski, A. (1934). Przewodnik społeczny. Dane monograficzno-orjentacyjne 250-ciu polskich stowarzyszeń i związków: 1: młodzieży, 2: b. wojskowych, 3: ogólnospołecznych, 4: kulturalno-oświatowych, 5: gospodarczych, 6: kobiecych, 7: Akcji Katolickiej, 7: zw. zawodowych, 8: różnych. Warszawa: Drukarnia P. Brzeziński.

\section{LITERATURA}

Badziak, K., Walicki, J. (2002). Żydowskie organizacje społeczne w Łodzi (do 1939 r.) [Jewish Social Organisations in Łódź]. Łódź: Ibidem.

Breza, E. (1998). Nazwy obiektów i instytucji związanych z nowoczesną cywilizacją (chrematonimy) [Names of Objects and Institutions Related to Modern Civilisation (Chrematonyms)]. W: E. Rzetelska-Feleszko (red.). Polskie nazwy własne. Encyklopedia [Polish Proper Names. Encyclopaedia] (s. 353-361). Warszawa-Kraków: TNW - IJP PAN.

Czopek-Kopciuch, B. (2011). Zachodnioeuropejskie poglądy na chrematonimię [Western European Views on Chrematonymy]. W: M. Biolik, J. Duma (red.). Chrematonimia jako fenomen współczesności [Chrematonymy as a Phenomenon of Modern Times] (s. 125-131). Olsztyn: Wydawnictwo Uniwersytetu Warmińsko-Mazurskiego.

Gałkowski, A. (2007). Socjoideonimy a chrematonimy - miejsce nazw organizacji i inicjatyw społecznych w dynamice onimicznej języka [Socioideonyms and Chrematonyms - the Status of the Names of Social Organisations and Activities in the Onymic Dynamics of the Language]. W: A. Cieślikowa, B. Czopek-Kopciuch, K. Skowronek (red.). Nowe nazwy własne - nowe tendencje badawcze [New Proper Names — New Research Trends] (s. 495-508). Kraków: Wydawnictwo PANDIT.

Gałkowski, A. (2011a). Chrematonimy w funkcji kulturowo-użytkowej. Onomastyczne studium porównawcze na materiale polskim, włoskim, francuskim [Chrematonyms in the Cultural-functional Context. An Onomastic Comparative Study Based on Polish, Italian and French Resources]. Łódź: Wydawnictwo Uniwersytetu Łódzkiego.

Gałkowski, A. (2011b). Chrematonomastyka jako autonomizująca się subdyscyplina nauk onomastycznych [Chrematonomastics as a Self-autonomising Subdiscipline of Onomastic Sciences]. W: M. Biolik, J. Duma (red.). Chrematonimia jako fenomen współczesności [Chrematonymy as a Phenomenon of Modern Times] (s.181-193). Olsztyn: Wydawnictwo Uniwersytetu Warmińsko-Mazurskiego.

Horecký, J. (1994). Logonomastika ako onomasticá disciplína [Logonomastics as a Discipline of Onomastics]. W: E. Krošláková (red.). Jazyková a mimojazyková stránka vlastných mien. 11. slovenská onomastická konferencia Nitra 19.-20. mája 1994. Zborník referátov (s. 76-78). Bratislava-Nitra.

Jakus-Borkowa, E. (2003). Chrematonimia kosmiczna. Nazewnictwo instytucji astronomicznych, programów badawczych, obserwatoriów do badania Układu Słonecznego oraz katalogów gwiazd [Outer Space Chrematonymy. Names of Astronomical Institutions, Research Programmes, Observatories for Examining the Solar System and Star Catalogues]. W: M. Biolik 
(red.). Metodologia badań onomastycznych [Methodology of Onomastic Studies] (s. 592-609). Olsztyn: Towarzystwo Naukowe. Ośrodek Badań Naukowych im. Wojciecha Kętrzyńskiego. Jakus-Borkowa, E. (1987). Nazewnictwo polskie [Polish Proper Names]. Opole: Wyd. WSP.

Jakus-Borkowa, E. (2004). Polskie nazewnictwo kosmiczne [Polish Outer Space Naming]. Opole: Wyd. Uniwersytetu Opolskiego.

Kaleta, Z. (1998). Teoria nazw własnych [Theory of Proper Names]. W: E. Rzetelska-Feleszko (red.). Polskie nazwy własne. Encyklopedia [Polish Proper Names. Encyclopaedia] (s. 15-36). Warszawa-Kraków: TNW - IJP PAN.

Kantyka, S. (2013). Stowarzyszenia w ustroju społeczno-politycznym Polski w latach 1918-1939. Studium historyczno-politologiczno-prawne [Associations in the Social-political System of Poland in the Period 1918-1939. A Historical-politological-legal Case Study]. Katowice: Wyd. Uniwersytetu Ekonomicznego.

Karamańska, M., Młynarczyk, E. (2018a). Językowy obraz troski o Rzeczpospolitą utrwalony w nazwach stowarzyszeń [A Linguistic Image of Care for the Second Polish Republic as Preserved in Associations' Names]. Annales Academiae Paedagogicae Cracoviensis. Studia Linguistica, XIII, s. 13-24.

Karamańska, M., Młynarczyk, E. (2018b). Identyfikacja osób w nazwach organizacji kombatanckich II Rzeczpospolitej [Identification of People in the Names of Combatant Organizations in the Second Polish Republic]. SŁOWO. Studia Językoznawcze, 9, s. 58-67.

Kosyl, C. (1993). Chrematonimy [Chrematonyms]. W: Encyklopedia kultury polskiej XX wieku [Encyclopaedia of Polish Culture in the 20th Century]. T. 2, J. Bartmiński (red.). Współczesny język polski [Contemporary Polish Language] (s. 439-444). Wrocław: Wiedza o Kulturze.

Krzysztofek, K. (2014). Stowarzyszenia katolickie w Krakowie w latach 1918-1939. Studium historycznoprawne [Catholic Associations in Cracow in the Period 1918-1939. A Historical-legal Case Study]. Kraków: Wyd. Uniwersytetu Jagiellońskiego.

Małocha-Krupa, A. (2018). Feminatywum w uwikłaniach językowo-kulturowych [Feminine Form in Linguistic-Cultural Complexities]. Wrocław: Oficyna Wydawnictwa ATUT.

Mańczak, W. (2011). Czy wszystkie chrematonimy są nazwami własnymi? W: M. Biolik, J. Duma (red.). Chrematonimia jako fenomen współczesności [Chrematonymy as a Phenomenon of Modern Times] (s. 325-329). Olsztyn: Wyd. Uniwersytetu Warmińsko-Mazurskiego.

Nowakowska, M., Odaloš, P. (1999). Nazwy organizacji politycznych i banków [Names of Political Organisations and Banks]. Zeszyty Naukowe WSHE w Łodzi. Filologia Polska. Językoznawstwo, 3 (5), s. 39-47.

SJPDor — Doroszewski, W. (red.) (1959-1968). Słownik języka polskiego [Polish Language Dictionary]. T. I-XI. Warszawa: PWN.

Suski, P. (2002). Stowarzyszenia w prawie polskim [Associations in Polish Law]. Warszawa: Wyd. Prawnicze LexisNexis.

Suski, P. (2008). Stowarzyszenia i fundacje [Associations and Foundations]. Warszawa: Wyd. Prawnicze LexisNexis.

Szelewski, M. (2004). Pragmatyczna interpretacja ergonimów komercyjnych na przykładzie nazw szkół językowych [Pragmatic Interpretation of Commercial Ergonyms, as Exemplified by Names of Language Schools]. Onomastica, XLIX, s. 165-179. 


\begin{abstract}
SUMMARY
TRENDS RELATED TO THE CREATION OF NAMES IN THE SOCIAL CHREMATONYMY OF THE SECOND POLISH REPUBLIC (BASED ON THE NAMES OF ASSOCIATIONS)
\end{abstract}

The paper is dedicated to the names of associations from the period of the Second Polish Republic, taken from a publication which is a guide to the rich and differentiated world of the social organizations of the 1930s.

The introduction is devoted to the state of Polish linguistic research into the names of organizations. The description of the collected material is based on the concept of social chrematonymy by Artur Gałkowski.

Next, the names are investigated from both a structural and a semantic perspective. The following elements are regarded as distinct qualities of the naming structures: descriptive character, multicomponent structure, development of right-sided attributives, insignificant share of names with a separate distinctive element, including some other types of proper names as components (toponyms, anthroponyms, names of historical events). Also, lexemes in the function of the main component of the analysed structures - nouns having the semantic value of 'formalized group of people' - have been presented.

When analysing the semantic aspect of names of organizations more closely, the author indicates the most frequently exposed bases of community feeling of members. Those could be: common experience, social and professional status, the purpose of activity, gender, generation, religious identity, nationality, ideology, place of activity or founding an organization. In the majority of names, various elements of community feeling are combined.

Finally, attention is paid to the tremendous informative value present in the names of associations, connected with their descriptive quality. The close link between socioideonyms and the reality they are connected with means that they are bearers of various historical-cultural contents. Therefore, the names of associations, especially historical ones, might be an interesting object of culture-oriented linguistic studies.

Keywords: chrematonymy, socioideonymy, names of associations, the Second Polish Republic 